\title{
The use of Instagram to improve students' analytical exposition text writing achievement at the second grade of SMAN 14 Bandar Lampung
}

\author{
Ranti Pratiwi $^{1}$, Ujang Suparman ${ }^{2}$, Gede Eka Putrawan ${ }^{3}$ \\ FKIP Universitas Lampung, Jl. Prof. Dr. Soemantri Brojonegoro No.1, \\ Bandar Lampung ${ }^{1,2,3}$ \\ Correspondence e-mail: rantipratiwi735@gmail.com
}

\begin{abstract}
The objectives of this research were to find out the significant difference of students ' writing achievement after using Instagram and to investigate the students 'perception of using Instagram in writing. The research was conducted among the second-grade students of SMA Negeri 14 Bandar Lampung in 2020/2021 academic year. The data were collected by using writing test and questionnaire. The data were collected by using writing tests (pre-test and post-test in the forms of analytical exposition text) and a closeended questionnaire. The data taken from the test were analyzed by using a Paired Sample T-test and the data collected by using the questionnaire were descriptively analyzed. The result showed that there is a significant difference of students 'writing achievement after the implementation of Instagram. It was also found that students ' perception of the implementation of Instagram was positive.
\end{abstract}

Keywords: Instagram, writing, perception.

\section{INTRODUCTION}

Social media can be defined as web-based and mobile technologies which are used mainly for communication. According to Taprial and Kanwar (2012) social media is the media that permitted to be social or get social by sharing with each other such as; content, news, photo, and others. Facebook, Twitter, Path, Pinterest, and Instagram are mostly common platforms of social media known by people (Handayani, 2016). It is a platform that provides interaction among people, when they can share, discuss and create information through social media. Instagram is one kind of social media used by people to comment, chat and share their moments.

Instagram becomes famous social media. It is stated by TechCrunch (2018) that Instagram has reached one billion monthly active users mark. Meanwhile, Statista (2019) stated that Indonesia is one of the countries with the most Instagram users with 60 million users. Instagram has a significant increasing user. Stated by Recode (2018) that Instagram users spent an average of 53 minutes per day. Maulina, Muslem, and Yuliana (2018) said that Instagram is a social media that focus on photo uploading and captioning where people share pictures and explain it in writing. In line with Al-Ali (2014) Instagram has the potential to be a language learning tool in terms of language skills.

Writing is one of the language skills which is important for students to master. Writing is the process of expressing ideas and thought to produce the final written based on the writers' ideas. This statement supported by Harmer (2004) writing is one of the productive skills in English where the students have to produce language by themselves. Based on Curriculum 13 for senior high school, the basic competency that should be achieved in the writing activity is that students have the ability to develop and produce a written text including narrative text, recount text, and analytical exposition. According to 
According to Gerot and Wignell (1994) analytical exposition text is a type of text that is intended to persuade readers that something should be in the case.According to Testi et al (2014) the communicative purpose of analytical exposition text is to influence the reader about the ideas or something related to the topic. From explanations of analytical exposition text above, it could be inferred that analytical exposition writing to persuade the reader with the ideas of the topic given.

While, Husna et al (2013) found that one of the students' difficulties in writing is students are still unable to transfer and develop their ideas into a written form well in composing a text. Based on a pre-observation at the second grade of SMAN 14 Bandar Lampung, the researcher found that many students faced difficulties in writing analytical exposition text. The students were unable to express their ideas in a written form. They got confused about how to start to write and how to develop their ideas. Therefore, their difficulties happened in expressing their ideas into a written text. The students also think that writing was a boring activity because they were not interested in writing.

Based on the researchers' pre-observation, English teachers need to find a solution to solvethe students' problems in writing. According to Richard (2015) many new technological tools and online resources are available to support student writing. Alfiyatun and Muntaha (2018) also said that media are important things to attract students' attention and motivation that can help them develop their creativity and imagination in expressing their ideas. Therefore, Instagram can be the solution to help students working on analytical exposition text. It is stated by Warda and Armeria (2019) using Instagram as learning media is an easy way to help students in writing skill. Therefore, the researcher uses media to teach writing by utilizing the internet and using a social network site. Besides, almost all students of SMAN 14 have an Instagram application installed onto it and also a mobile data plan.

According to Ardi (2009) stated that learners use online learning environments not only to access information and course content but also to interact and collaborate with other participants in the same course. The ability to connect with other students, to share information, to chat and communicate as the benefit of the implementation of online activities in teaching and learning through Instagram.

Besides the theories, the implementation of Instagram as a medium to help students improve their writing achievement has also been reported. Listiani (2016) states that teaching recount text using Instagram resulted in better achievement. Besides, Instagram can also be used to improve students' opinion essays text writing (Handayani, Cahyono, and Widiati 2018). Therefore, Instagram can be widely accepted as a medium for helping students improve their writing ability.

Based on those previous researches, it could be inferred that those studies have proved that Instagram is a good medium to be implemented for teaching writing skill especially for helping students to improve their writing achievement. The focus of this research is to find out the significant difference of students' writing achievement and also to know the students' perceptions of using Instagram in writing.

\section{METHODS}

This research used a quantitative method which aimed to find out the significant difference of students' writing achievement after using Instagram and to investigate the 
students' perception of using Instagram in writing. The population of the research was the second-grade students of SMA Negeri 14 Bandar Lampung. The sample was 28 students of XI Science 1. This study used a purposive sampling technique. The data were collected from the writing tests (pre-test and post-test in the forms of analytical exposition text)) and a close-ended questionnaire. The data taken from the tests were analyzed by using a Paired Sample T-test and the data collected by using the questionnaire were descriptively analyzed.

\section{RESULTSAND DISCUSSIONS}

\section{Results of the Tests}

This section presents the result of data analysis. For the test result, the improvement in each aspect can be seen from the following table:

\begin{tabular}{cccccc}
\hline $\begin{array}{c}\text { Aspects of } \\
\text { Writing }\end{array}$ & $\begin{array}{c}\text { Mean score } \\
\text { of Pre-test }\end{array}$ & $\begin{array}{c}\text { Mean score } \\
\text { of Post-test }\end{array}$ & $\begin{array}{c}\text { Gain } \\
\text { Score }\end{array}$ & $\begin{array}{c}\text { Maxi-mum } \\
\text { Score }\end{array}$ & Sig. \\
\hline Content & 16.98 & 22.63 & 5.65 & 30 & .000 \\
\hline Organization & 14.27 & 16.71 & 2.44 & 20 & .000 \\
\hline Vocabulary & 14.45 & 17.05 & 2.6 & 20 & .000 \\
\hline Grammar & 16.04 & 20.25 & 4.21 & 25 & .000 \\
\hline Mechanics & 3.32 & 3.85 & 0.53 & 5 & .000 \\
\hline
\end{tabular}

Table 4.1 The improvement of the students' achievement in analytical exposition text writing

Table 4.1. above provides the data of students' writing scores in pre-test, scores in posttest, gain scores, maximum score then the percentage for each aspect of writing. According to the table, the highest gain score of each aspect is content with (5.65) followed by grammar (4.21). Then, the gain score of the vocabulary, organization and mechanics are (2.6), (2.44) and (0.53). Furthermore, there is a significant difference in all aspects of writing including content, organization, vocabulary, grammar, and mechanics because 0.00 is less than 0.05 .

To find out whether the improvement was significant or not, Paired Sample T-Test in SPSS version 20 was used in this research. The following table shows the result of Paired Samples T-Test.

Table 4.2 Paired Samples T-Test

\begin{tabular}{lllll}
\hline Paired Differences & T & D & Sig. \\
\hline
\end{tabular}




\begin{tabular}{|c|c|c|c|c|c|c|c|c|c|}
\hline & & \multirow[t]{2}{*}{ Mean } & \multirow[t]{2}{*}{$\begin{array}{l}\text { Std. } \\
\text { Devi } \\
\text { ation }\end{array}$} & \multirow{2}{*}{$\begin{array}{c}\text { Std. } \\
\text { Erro } \\
\text { r } \\
\text { Mea } \\
\text { n }\end{array}$} & \multicolumn{2}{|c|}{$\begin{array}{l}\text { 95\% Confidence } \\
\text { Interval of the } \\
\text { Difference }\end{array}$} & & \multirow[t]{2}{*}{$\mathrm{f}$} & \multirow[t]{2}{*}{$\begin{array}{c}(2- \\
\text { tailed) }\end{array}$} \\
\hline & & & & & Lower & Upper & & & \\
\hline $\begin{array}{l}\mathrm{P} \\
\text { ai } \\
\mathrm{r} \\
1\end{array}$ & $\begin{array}{l}\text { PO } \\
\text { ST } \\
\text { TE } \\
\text { ST } \\
- \\
\text { PR } \\
\text { E } \\
\text { TE } \\
\text { ST }\end{array}$ & $\begin{array}{r}15.44 \\
643\end{array}$ & $\begin{array}{r}3.016 \\
43\end{array}$ & $\begin{array}{r}.570 \\
05\end{array}$ & $\begin{array}{r}14.27 \\
678\end{array}$ & $\begin{array}{r}16.61 \\
608\end{array}$ & $\begin{array}{r}27.0 \\
97\end{array}$ & $\begin{array}{l}2 \\
7\end{array}$ & .000 \\
\hline
\end{tabular}

Table 4.2 provides evidence that the result shows that the two tailed significance is 0.000 . It indicates that $\mathrm{H}_{1}$ is accepted because 0.00 is less than $0.05(0.00<0.05)$. It proves that there is a significant difference on students 'writing achievement after the implementation of Instagram.

\section{Result of the Questionnaire}

This section presents the result from the second research question which aims to investigate the students 'perception of using Instagram in writing which is based on five aspects (difficulty, stress, interest, motivation, and confidence). The frequency and percentage of each aspect of the questionnaire are described below:

\section{Difficulty}

This section describes specifically the result on the first, second and third statements which concern with aspect of difficulties. The table of result in difficulty aspect is presented below:

\begin{tabular}{|c|c|c|c|c|c|c|c|c|}
\hline \multirow{3}{*}{ STATEMENT } & \multicolumn{8}{|c|}{ OPTION } \\
\hline & \multicolumn{2}{|c|}{$\begin{array}{l}\text { Strongly } \\
\text { Agree (4) }\end{array}$} & \multicolumn{2}{|c|}{$\begin{array}{c}\text { Agree } \\
(3)\end{array}$} & \multicolumn{2}{|c|}{$\begin{array}{c}\text { Disagree } \\
\text { (2) }\end{array}$} & \multicolumn{2}{|c|}{$\begin{array}{c}\text { Strongly } \\
\text { Disagree } \\
\text { (1) }\end{array}$} \\
\hline & $\mathrm{F}$ & $\%$ & $\mathrm{~F}$ & $\%$ & $\mathrm{~F}$ & $\%$ & $\mathrm{~F}$ & $\%$ \\
\hline $\begin{array}{l}\text { It is easy to share writing } \\
\text { content through Instagram. }\end{array}$ & 5 & 17.9 & 20 & 71.4 & 2 & 7.1 & 1 & 3.6 \\
\hline $\begin{array}{l}\text { Instagram is accessible to } \\
\text { discuss the material. }\end{array}$ & 1 & 3.6 & 22 & 78.6 & 4 & 14.3 & 1 & 3.6 \\
\hline
\end{tabular}


It is easy for me to follow the online learning process on $4 \begin{array}{lllllllll} & 4 & 14.3 & 21 & 75.0 & 3 & 10.7 & - & -\end{array}$ Instagram.

Table 4.3 The frequency and percentage of difficulty

Table 4.3 presents the frequency and percentage from students 'answer in aspect of difficulty. It can be clearly seen that most of the students agree in the first statement at percentage $(71.4 \%)$, followed by strongly agree in with percentage $(17.9 \%)$ with total responses of 20 and 5 students respectively. Then, for the second statement, the highest percentage is $(78.6 \%)$ agree with that statement with a total response of 22 students. Turning to the third statement, it is apparent that 21 students agreed $(75.0 \%)$ with that statement. The mean score for the aspect is $73.83 \%$. It can be concluded that the students believed by using Instagram in writing made them easier to share and discuss the material.

\section{Stress}

This section presents the result on the fourth, fifth and sixth statement which concerns with aspect of stress. The table of result in stress aspect is presented below:

Table 4.4 The frequency and percentage of stress

\begin{tabular}{|c|c|c|c|c|c|c|c|c|}
\hline \multirow{3}{*}{ STATEMENT } & \multicolumn{8}{|c|}{ OPTION } \\
\hline & \multicolumn{2}{|c|}{$\begin{array}{l}\text { Strongly } \\
\text { Agree (4) }\end{array}$} & \multicolumn{2}{|c|}{$\begin{array}{c}\text { Agree } \\
(3)\end{array}$} & \multicolumn{2}{|c|}{$\begin{array}{c}\text { Disagree } \\
\text { (2) }\end{array}$} & \multicolumn{2}{|c|}{$\begin{array}{c}\text { Strongly } \\
\text { Disagree } \\
\text { (1) }\end{array}$} \\
\hline & $\mathrm{F}$ & $\%$ & $\mathrm{~F}$ & $\%$ & $\mathrm{~F}$ & $\%$ & $\mathrm{~F}$ & $\%$ \\
\hline $\begin{array}{l}\text { Online learning through } \\
\text { Instagram group chat makes } \\
\text { me relax to learn in English } \\
\text { writing. }\end{array}$ & 4 & 14.3 & 19 & 67.9 & 5 & 17.9 & - & - \\
\hline $\begin{array}{l}\text { Instagram makes me more } \\
\text { enjoy to share my thoughts } \\
\text { with my friends. }\end{array}$ & 3 & 10.7 & 18 & 64.3 & 7 & 25.0 & - & - \\
\hline $\begin{array}{l}\text { I like to do English writing } \\
\text { tasks on Instagram. }\end{array}$ & 7 & 25.0 & 14 & 50.0 & 7 & 25.0 & - & - \\
\hline
\end{tabular}

Table 4.4 provides the frequency and percentage from students 'answer in aspect of stress. The highest response was agreed $(67.9 \%)$ on statement 4 , followed by disagree (17.9\%) with total responses of 19 and 5 students. For statement 5, it can be seen that the majority of students agree that Instagram made them enjoy to share their thoughts with 
their friends $64.3 \%$. Then, 14 students who were agreed (50.0\%) with statement 6 . It is followed by strongly agree and disagree scales have the same pattern in which for strongly agree and disagree have 7 responses in percentage of $25.0 \%$. Finally, the results for this aspect are most of students showed positive perception $73.50 \%$.

\section{Interest}

This section presents specifically the result on statements 9, 10 and 11 (Aspect of Interest). The frequency and percentage of students 'answers are presented in the table below:

Table 4.5 The frequency and percentage of interest

\begin{tabular}{|c|c|c|c|c|c|c|c|c|}
\hline \multirow{3}{*}{ STATEMENT } & \multicolumn{8}{|c|}{ OPTION } \\
\hline & \multicolumn{2}{|c|}{$\begin{array}{l}\text { Strongly } \\
\text { Agree (4) }\end{array}$} & \multicolumn{2}{|c|}{$\begin{array}{l}\text { Agree } \\
\text { (3) }\end{array}$} & \multicolumn{2}{|c|}{$\begin{array}{l}\text { Disagree } \\
\text { (2) }\end{array}$} & \multicolumn{2}{|c|}{$\begin{array}{c}\text { Strongly } \\
\text { Disagree } \\
\text { (1) }\end{array}$} \\
\hline & $\mathbf{F}$ & $\%$ & $\mathbf{F}$ & $\%$ & $\mathbf{F}$ & $\%$ & $\mathbf{F}$ & $\%$ \\
\hline $\begin{array}{l}\text { Learning writing through } \\
\text { Instagram is interesting. }\end{array}$ & 7 & 25.0 & 19 & 67.9 & 2 & 7.1 & - & - \\
\hline $\begin{array}{l}\text { I have an interest to write in } \\
\text { English on Instagram. }\end{array}$ & 4 & 14.3 & 15 & 53.6 & 9 & 32.1 & - & - \\
\hline $\begin{array}{l}\text { Instagram keeps my } \\
\text { attention; I do not get bored } \\
\text { during the learning process } \\
\text { using Instagram. }\end{array}$ & 5 & 17.9 & 21 & 75.0 & 2 & 7.1 & - & - \\
\hline
\end{tabular}

According to table 4.5 above, it can be clearly seen that the majority of students (19 students) agreed on statement 7 with the total percentage $67.9 \%$. It is followed by seven students who were strongly agreed with the percentage $25.0 \%$. For the statement 8 , most of students (15 students) agreed with that statement (53.6\%), followed by disagree in with percentage (32.1\%) with a total response of 9 students. Then, the rest of students (21 students) agreed (75.0\%) on statement 9. Thus, the result showed that students were interested in writing through Instagram $75.88 \%$.

\section{Motivation}

This section presents specifically the result on statements 10,11 and 12 (Aspect of Motivation). The frequency and percentage of students 'answers are presented in the table below:

Table 4.6 The frequency and percentage of motivation

STATEMENT OPTION




\begin{tabular}{|c|c|c|c|c|c|c|c|c|}
\hline & \multicolumn{2}{|c|}{$\begin{array}{l}\text { Strongly } \\
\text { Agree } \\
\text { (4) }\end{array}$} & \multicolumn{2}{|c|}{$\begin{array}{l}\text { Agree } \\
(3)\end{array}$} & \multicolumn{2}{|c|}{$\begin{array}{l}\text { Disagree } \\
\text { (2) }\end{array}$} & \multicolumn{2}{|c|}{$\begin{array}{c}\text { Strongly } \\
\text { Disagree } \\
\text { (1) }\end{array}$} \\
\hline & $\mathrm{F}$ & $\%$ & $\mathrm{~F}$ & $\%$ & $\mathrm{~F}$ & $\%$ & $\mathrm{~F}$ & $\%$ \\
\hline $\begin{array}{l}\text { I feel motivated to write } \\
\text { English through Instagram. }\end{array}$ & 6 & 21.4 & 14 & 50.0 & 6 & 21.4 & 2 & 7.1 \\
\hline $\begin{array}{l}\text { I am trying to participate } \\
\text { well in Online learning on } \\
\text { Instagram. }\end{array}$ & 9 & 32.1 & 18 & 64.3 & 1 & 3.6 & - & - \\
\hline $\begin{array}{l}\text { I did all the learning } \\
\text { activities on Instagram; it } \\
\text { makes my writing skill } \\
\text { improved. }\end{array}$ & 6 & 21.4 & 16 & 57.1 & 5 & 17.9 & 1 & 3.6 \\
\hline
\end{tabular}

From the table 4.6 above, it is apparent that there are 14 students who agreed on statement 10 with the percentage of $(50.0 \%)$ and six students have the same percentage (21.4\%) in which for strongly agree and disagree. Then, the highest response for statement 11 was agreed $(64.3 \%)$ with a total response of 18 students. It is followed by students who were strongly agreed ( 9 students) with the percentage of $32.1 \%$. Meanwhile, there are 16 students who agreed $57.1 \%$ on statement 12 . Most of the students showed positive responses toward each statement. The students believed that using Instagram in Online learning gave them motivation in writing analytical exposition $75.88 \%$.

\section{Confidence}

This section provides the result of students 'answers regarding Statement 13, 14 and 15 (Aspect of Confidence). The frequency and percentage of students 'answers are presented in the table below:

Table 4.7 The frequency and percentage of confidence

\begin{tabular}{cccccccccc}
\hline & \multicolumn{8}{c}{ OPTION } \\
\cline { 2 - 9 } STATEMENT & $\begin{array}{c}\text { Strongly } \\
\text { Agree (4) }\end{array}$ & $\begin{array}{c}\text { Agree } \\
(3)\end{array}$ & $\begin{array}{c}\text { Disagree } \\
(2)\end{array}$ & $\begin{array}{c}\text { Strongly } \\
\text { Disagree } \\
(1)\end{array}$ \\
& & & & & & & & & \\
& & F & $\%$ & F & $\%$ & F & $\%$ & F & $\%$ \\
\hline $\begin{array}{l}\text { Learning through Instagram } \\
\text { can build up my self- }\end{array}$ & 6 & 21.4 & 17 & 60.7 & 4 & 14.3 & 1 & 3.6 \\
\hline
\end{tabular}


confidence.

I am not afraid to express my
opinion or suggestion on
Instagram.

My writing skill is improved after the implementation of $\begin{array}{llllllllll}7 & 25.0 & 14 & 50.0 & 7 & 25.0 & - & -\end{array}$ Instagram.

From the table 4.7 above, it can be seen in the statement 13, most of the students agree at percentage $(60.7 \%)$ with a total response of 17 students. Then it was followed by six students who were strongly agreed $21.4 \%$. Turning to the statement 14 , it presented that 19 students agreed in with percentage $67.9 \%$. The highest response for statement 15 was agreed $(50.0 \%)$ with a total response of 14 students. It is followed by strongly agree and disagree scales have the same pattern in which for strongly agree and disagree have 7 responses in percentage of (25.0\%). The mean score of this aspect is $(75.59 \%)$, it could be summarized that students with good confidence in learning English through Instagram.

\section{Discussions}

The research finding indicates that the students 'achievement in analytical exposition text writing significantly difference after the implementation of Instagram at the second grade of SMAN 14 Bandar Lampung. It could be seen from data presented in table 4.2 that the significant level of students 'improvement is 0.000 which is lower than $0.05(0.00<0.05)$. The students 'mean score in the pre-test was 65.05 and the post-test was 80.50. Therefore, it indicates that the implementation of Instagram could increase students 'writing achievement. This research result is in line with the previous researcher by Warda and Armeria (2019) that by using social media "Instagram" as a medium in teaching writing to improve students 'writing ability is useful tool to help the students being mastered on writing.

From the result of gain score, the improvement was shown in every aspect of writing which were content (5.65), organization (2.44), vocabulary (2.6), grammar (4.21), and mechanics (0.53). It could be inferred that the content became the most improved aspect compared to the others. The finding of this research resonates with Renaldi (2020) finding that Instagram was effective in improving the students 'writing skill in term of content. Moreover, the students seemed to be more attracted, they were gathered on the group with their friends to discuss the topic that they were going to write. It helps students to explore their ideas to write into a good paragraph. It is in line with Handayani (2016) who said that Instagram helps students to generate their ideas with relevant content. Therefore, it can make them enthusiast to learn writing an analytical exposition text because they felt attracted using Instagram as learning media. 
On the other side, the media could also attract the students 'interest to learn in writing. It is in line with the findings of the research conducted by Irawan (2015) that social medium can make a lesson become more interesting and more attractive. Moreover, by using Instagram, the lesson became more effective since the students did not need paper to submit their writing tasks. They just used their smartphones to upload their writing tasks on Instagram and then their teacher would get their tasks. Then, by using Instagram used less paper because it was done through Instagram. Moreover, the students could access Instagram everywhere as long as the internet connection was available. It is in line with the findings of the research conducted by Zidny (2017) which stated that the use of Instagram can make the lesson become more effective and efficient in terms of time, energy, and equipment. Therefore, it could be stated that after getting some treatments using Instagram, students 'writing achievement improved well.

Based on the result of the questionnaire, it was found that $(74.93 \%)$ students had a positive perception toward the implementation of Instagram since the percentage is more than $70 \%$. In other words, the students 'perception was good enough after the implementation of Instagram in online learning. Based on the result of students ' responses in the questionnaires above, it could be concluded that students with positive perception were interested in learning writing by using Instagram as a medium in online learning.

\section{CONCLUSIONS AND SUGGESTIONS}

\section{Conclusions}

In line with the discussion of the research findings in the previous chapter,the researcher comes to the conclusion that there is a significant difference of students 'writing achievement after using Instagram. It could be seen from the computation of the value of two tailed is significance is 0.00 which is lower than 0.05 . Moreover, the students get better writing achievement after the implementation of Instagram. It is proved by the

students 'writing mean score in the pre-test (65.05) and post-test (80.50). It was also found that students had a positive perception after the implementation of Instagram. Therefore, it can be concluded that students were interested and enjoyed during the learning process through Instagram.

\section{Suggestions}

In reference to the conclusion above, there are some suggestions to the English teacher and the further researcher are proposed as follows. First, the teacher should provide students with interesting media to support the learning process in this technology era such as Instagram that provides space for writing. The teacher should be creative to enhance students' participation in online learning. Moreover, the teacher can provide interesting pictures or videos in the learning process. It hopes to make students have more interesting during online learning. Next, for the further researchers can mix the online setting with offline learning (face to face) in order to support the teaching-learning activities. This researcher was done in an online setting. For the further researcher, it is suggested to use video call in order to make sure that students do not cheat when they do the writing test. 
The further researcher can try to find out the responses, motivation or attitude of the students.

\section{REFERENCES}

Al-Ali, S. (2014). Embracing the selfie craze: Exploring the possible use of Instagram as a language mlearning tool. Sharjah: Issues and trends in Educational Technology, 2 (2).

Alfiyatun and Muntaha. (2018). The effectiveness of Instagram captions to teach writing (An experimental research on the tenth-grade students of SMA Muhammadiyah 1 Karanganyar in academic year 2017/2018). Surakarta: Institut Agama Islam Negeri Surakarta, 2018.

Ardi, H. (2009). Internet-based activities in developing students 'English skills. International seminar conducted by Indonesian English teacher association in $\begin{array}{llll}\text { Padang, } & 6 & \text { (1). } & \text { Retrieved }\end{array}$ http://ejournal.unp.ac.id/index.php/linguadidaktika/ article/view/7397/5817

Gerot, L. and Wignell,P. (1994). Making sense of functional grammar. Sydney: Antepodean Educational Enterprises.

Handayani, F. (2016). Instagram as a teaching tool? really. Proceedings of the fourth International seminar on English Language and Teaching (ISELT-4), 4 (1).

Handayani, A. D., Cahyono, B. Y., and Widiati, U. (2018). The use of Instagram in the teaching of EFL writing: effect on writing ability and students 'perceptions. East Java: English Language Teaching, 6 (2). Retrieved from http://dx.doi.org/10.22 158/selt.v6n2p112

Harmer, J. (2004). How to teach writing. England: Person Education Limited

Husna, L., Zainil., and Rozimela, Y. (2013). An analysis of students 'writing skill in descriptive text at grade XI IPA 1 of MAN 2 Padang. West Sumatra: Journal English Language Teaching (ELT), 1 (2).

Irawan, R. (2015). Improving the writing learning process of grade VIII students of SMP $N 1$ Pleret through Facebook group in the academic year of 2014/2015. Yogyakarta: Program Studi Pendidikan Bahasa Inggris, FBS UNY.

Listiani, G. (2016). The effectiveness of Instagram writing compared to teacher centered to teach recount text to student with high and low motivation. UNNES journal of English Language Teaching, 5 (1).

Maulina, C. R., Muslem, A., and Yuliana. (2018). An analysis of students 'ability in writing caption through Instagram.Aceh: Research in English and Education (READ), 3 (1), 08-16.

Recode. (2018). Minutes spent per day on social apps.https://www.vox. com/2018/6/25/17 501224/instagram-facebook-snapchat-time-spent-growth-data

Renaldi, S. (2020). Using Instagram to improve students 'ability and interest in writing descriptive paragraph. Journal La Edusci University of Muhammadiyah Makassar, 1(1). Retrieved from https://media.neliti.com/media/publications/299329-using instagr am-to-improvestudents-abil-0f62211b.pdf 
Richard, J.C. (2015). Key issues in language teaching. Cambridge:Cambridge University Press.

Statista. (2019). Leading countries based on number of Instagram users as of october 2019 (in millions). https://www.statista.com/statisttics/578364/countries-withmost-inst agram-users/

Taprial, V. and Kanwar, P. (2012). Understanding social media. London: Ventus Publishing ApS.

TechCrunch. (2018).Instagram hits 1 billion monthly users, up from $800 \mathrm{M}$ in september.https://techcrunch.com/2018/06/20/instagram-1-billion-users/

Testi, R., Harmaini, F., and Yandri. (2014). Teaching writing analytical exposition text by using mind mapping. Bung Hatta University Journal, 3 (6), 2. Retrieved from http://ejurnal.bunghatta.ac.id/index.php?journal=JFKIP\&page $=$ article \&op=view \&path\%5B $\% 5 \mathrm{D}=3661$

Warda, E. G. and Armeria, W. (2019). The effectiveness of teaching writing descriptive text by using social media "Instagram" to improve students 'writing ability at junior high school students. Surabaya: Tell Teaching of English Language and Literature Journal, 7 (1), 16. Retrieved from Doi: http://dx.doi.org/10. 30651/tell.v7i1.2696

Zidny, I. (2017). Improving students writing skill using Instagram in grade X of Science 5 SMAN 5 Yogyakarta. Malang: Universitas Negeri Malang. 